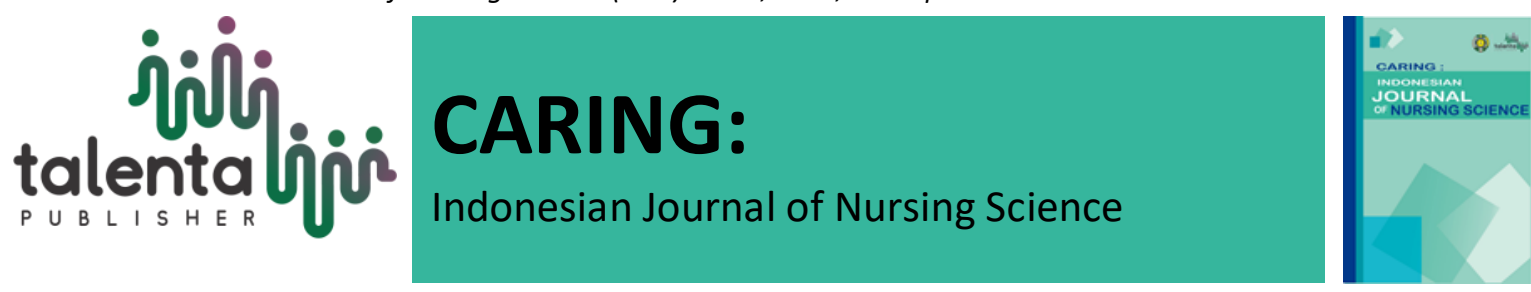

\title{
Effectiveness of Suctioning and Factors Affecting ; A Systematic Review
}

\section{Hendy Lesmana}

Faculty of Health Science, University of Borneo Tarakan

\begin{abstract}
Suction is a routine action performed by nurses who work in a critical care setting. every patient who has decreased consciousness and installed a definitive airway will always get a suction action that is useful for keeping the airway free of mucus so that airway patency is maintained. The purpose of this literature review is to identify and summarize the results of research and books on factors that influence the effectiveness of suction. This study is a literature review that tries to find and explore more information about the effectiveness of suction. The method used in this literature review begins with topic selection, keyword determination to search journals through the Google Scholar, EBSCO, and Pro Quest databases. The articles used were 16 articles and 7 books. Literature search results obtained namely; factors affecting the effectiveness of suction are; assessment before performing suction, prehyper oxygenation measures, effective suction pressure regulation, suction canule size must pay attention to the ETT diameter / size, suction action time 10-15 seconds for adults and 5 seconds for infants and children, suction techniques and must consider volume and mucus viscosity. The conclusion in conducting effective suction, nurses must pay attention to these 7 factors rather in the implementation of suction actions to be more effective and avoid unwanted side effects.
\end{abstract}

Keyword: Effectiveness, Suction.

Received 10 October 2019 | Revised 28 December 2019 | Accepted 29 January 2019

\section{Introduction}

Suction (suction) is aspiration of secretions through a catheter which is connected to the suction machine or suction channel that is on the wall. Suction can be done through the nasopharynx, oropharynx and endotracheal intubation (through the endotracheal tube or through the tracheostomy tube). Suction is the most frequent and important nursing action in a critical nursing setting, every patient who has decreased consciousness and gets the definitive airway installation will always get suction.

Nurses who work in the intensive care room must have good knowledge and skills in performing suction so that it can reduce / avoid complications that occur due to the suction

*Corresponding author at: Jl. Prof.Maas No. 03 Kampus USU, Medan, Indonesia.

E-mail address: hendylesmana2@gmail.com

Copyright (c) 2019 Published by Talenta Publisher

e-ISSN: 2685-7162

Journal Homepage: https://talenta.usu.ac.id/IJNS 
action. Based on the author's observations there are still nurses who work in intensive rooms and nurses who work in care rooms do not yet know the correct suction technique. The purpose of this literature review is to identify and summarize the results of research and books on factors that influence the effectiveness of suction.

\section{Methods}

This study is a literature review that tries to find and explore more information about suction, starting from the assessment, pre-hyper oxygenation of suction pressure, suction catheter size, suction duration, suction technique and mucus volume and viscosity. The method used in this systematic review begins with topic selection, keyword determination for searching English and Indonesian journals through the Google Scholar, EBSCO, and Pro Quest databases. The journal year is limited from 2000 to 2019 using the English keyword "suctioning", for the Indonesian language using the keyword "pengisapan".

\section{Result}

Journals are selected for review based on studies that fit the inclusion criteria. The inclusion criterion in the systematic review is the use of factors that influence suction action. A search using the above keywords found 25 journals. From all the journals obtained that are in accordance with the theme are 16 articles. While there are 7 books used for this literature review.

\section{Discussion}

Suction is aspiration of secretions through a catheter which is connected to the suction machine or suction channel that is on the wall. Endotracheal and tracheostomy suction are important interventions in treating patients with an artificial airway and are an important aspect of effective airway management in critical patients (Berman, Snyder, Kozier, \& Erb, 2009; Kelleher \& Andrews, 2008).

Suction technique is divided into two parts, namely: suction in the upper airway (oropharynx and nasopharynx) and suction in the endotracheal tube or tracheostomy. Artificial oropharyngeal and nasopharyngeal airway suction is used for patency of the upper airway during obstruction by secretions. Suction through the endotracheal tube and tracheostomy is performed to secrete and maintain airway patency and prevent pneumonia due to accumulation of secretions (Berman, Snyder, Kozier \& Erb, 2009; Kelleher \& Andrews, 2008).

Based on research conducted by Kelleher and Andrews (2008) that nurses do suction only based on a habit and not based on the results of a study. The results of this study stated that 45 nurses (respondents) who worked in the intensive room (CICU and GICU) showed low quality in 
conducting suctioning $(\mathrm{p}<0.01)$. Suctioning is an important nurse intervention when treating critical patients, suctioning that is done inappropriately can cause hypoxemia, hypoxia, tracheal mucosal injury, infection, even atelectasis. So we need a caution and suction technique according to the procedure in ensuring the effectiveness of actions and patient safety.

In conducting suction there are several things that affect the effectiveness of the action including:

\subsection{Assess the Patient Before Suctioning}

In increasing the effectiveness of suctioning, it is better to do an assessment on the patient, including chest auscultation before and after the procedure. Patient preparation also needs to be done before suctioning is done. Suctioning can cause increased pain and discomfort, so an explanation is needed to the patient before and after suction (Day, Farnell, Haynes, Wainwright \& Barnett, 2002).

\subsection{Pre Hyper Oxigenation}

Suction can cause hypoxemia, dysrhythmias and hypotension so pre-hyper oxygenation needs to be done before and after suctioning. Pre-hyper oxygenation is given for 30 seconds - 2 minutes before suctioning is done or when oxygen saturation has reached $>95 \%$, then pre-hyper oxygenation is sufficient. After suctioning, pre-hyper oxygenation can be given for 30 seconds 2 minutes until oxygen saturation reaches $>95 \%$. Pre-hyper oxygenation is done by giving oxygen with a concentration of $100 \%$ can use a ventilator setting (FiO2 100\%) or use a bag valve mask with a reservoir where the flow rate of 10-15 liters / minute. Pre-hyper oxygenation can also be done by using other breathing aids by increasing oxygen flow to the maximum (depending on the breathing aid used) until oxygen saturation of more than $95 \%$ is achieved. The recommended time after performing suction and immediately connecting the oxygen source to the endotracheal tube / tracheostomy is less than 10 seconds to prevent hypoxia (Day, Farnell, Haynes, Wainwright \& Barnett, 2002; Berman, Snyder, Kozier \& Erb, 2009; Hahn, 2010).

Pre oxygenation by using a ventilator setting (100\% FiO2) or using a bag valve mask with a reservoir where the flow amount of 10 liters / minute is proven to increase oxygen saturation by $100 \%$. This is demonstrated by research conducted by Smith, et. al. (1987) which states there is no significant difference in the two pre oxygenation protocols before suction between giving $100 \% \mathrm{FiO} 2$ to the ventilator and giving 10 liters / minute using a bag valve mask with a reservoir ( $p>0.05$ ) in patients with ventilators, where both protocols can increase saturation up to $100 \%$. In principle, the action of pre oxygenation must still be done to prevent hypoxemia in patients who are suctioned.

In a study conducted by $\mathrm{Oh}$ and Seo (2003) pre oxygenation before suctioning can reduce the incidence of hypoxemia due to suction by $32 \%$, while pre oxygenation actions performed before and after suctioning can reduce the number of hypoxemia due to suctioning by $49 \%$. 


\subsection{Suction Pressure}

Suction pressure regulation is very important in determining the effectiveness of suctioning performed. The use of appropriate suction pressure can increase evacuation of secretions from the airway and minimize side effects from suctioning. There are many differences of opinion in assigning negative pressure to suctioning, so Kelleher and Andrews (2006) at the end of their study recommend to put more emphasis on further research on the determination of effective negative pressure suction, measurement of infection control and the best procedure for hyper oxygenation.

Research conducted by Day, Farnel, Haynes, Wainwright and Barnett (2002) recommends the use of low suction pressure to minimize the side effects of these actions including the incidence of atelectasis, hypoxia, and tracheal mucosal damage. Research conducted by Oh and Seo (2003) that the regulation of suction pressure must be adjusted to the size of the suction catheter and the number of mucus that is present in the patient, so that further research is needed on this subject (Pedersen, Nielsen, Hjermind \& Egerod, 2008).

Woodward and Mestecky (2011) recommend a pressure of 100-150 $\mathrm{mmHg}$ (14-20 kPa). If secretions cannot be evacuated, do not increase the negative pressure of suction but must first be nebulised. This is contrary to Hahn (2010) who recommends a suction pressure between 80-150 $\mathrm{mmHg}$ and if the secretions are difficult to evacuate, the suction pressure can be increased to $200 \mathrm{mmHg}$. Day, Farnel, Haynes, Wainwright and Barnett (2002) recommend the use of a suction pressure of $80-150 \mathrm{mmHg}$ (11-20 $\mathrm{kPa}$ ) if exceeding this can cause injury, hypoxemia and atelectasis. Kozier, et.al. (2011) recommend the use of suction pressure in adult patients between $100 \mathrm{mmHg}-120 \mathrm{mmHg}$. Berman, et.al (2009) recommends negative suction pressure in adult patients of $100 \mathrm{mmHg}-120 \mathrm{mmHg}$. Seen from the description above there is a lack of uniformity in determining the negative suction pressure.

$100 \mathrm{mmHg}$ pressure is the minimum negative pressure recommended for suction but suction pressure can be adjusted based on the number and characteristics of the secretions found in the airway, if the pressure of $100 \mathrm{mmHg}$ cannot mobilize the secretions then the pressure can be increased to $120 \mathrm{mmHg}$, the pressure can be up to $150 \mathrm{mmHg}$ because if more than this pressure can cause airway injury and hypoxia (Potter \& Perry, 2010; Hahn, 2010; Day, Farnel, Haynes, Wainwright \& Barnett, 2002). American Association for Respiratory Care; Guidelines for endotracheal suctioning of mechanically ventilated and artificial airways (2010) state that regulation of suction pressure in adult patients up to a maximum limit of $150 \mathrm{mmHg}$ and recommends the use of suction pressure in adults ranging from $100 \mathrm{mmHg}-150 \mathrm{mmHg}$. The use of pressure in the range of 100-150 $\mathrm{mmHg}$ can also evacuate the secretions from the airways in patients who are fitted with airway aids. Research Seymour, et.al. (2009), the use of suction pressures $\geq 200 \mathrm{mmHg}$, causes a high incidence of hemodynamic instability both in the use of closed suction or open suction. 
Based on research conducted by Cereda, et.al. (2001), the use of $100 \mathrm{mmHg}$ suction pressure causes a loss of air volume in the lungs around $140 \mathrm{ml} / \mathrm{min}$ (in closed suction) and as much as $1,200 \mathrm{ml} / \mathrm{min}$ in the use of open suction. Almgren Wickert, Heinonen, and Hogman (2004) conducted research on the side effects of endotracheal suction at suction pressure of $100 \mathrm{mmHg}$ with ventilator pressure and volume control for tidal volume and $\mathrm{PaO} 2$, where there was a change in tidal volume 1 minute after suction in the ventilator pressure control mode. $291+81$ $\mathrm{ml}$ (baseline: $395+28 \mathrm{ml}$ ) and the ventilator volume control mode there is a tidal volume change of $388+24 \mathrm{ml}$ (baseline: $389+26 \mathrm{ml}$ ).

Research conducted by Corley, et.al. (2010) the use of $120 \mathrm{mmHg}$ suction pressure causes loss of about 2 liters / minute of air, so pre-hyper oxygenation is needed before and after suctioning to prevent air / oxygen loss in the lungs.

Research conducted by Heinze, et.al. (2008) the use of $150 \mathrm{mmHg}$ suction pressure can cause changes in tidal volume, where in closed suction the change in tidal volume before suction is $495+103 \mathrm{ml}$ to $465+102 \mathrm{ml}$ (after suction) and in open suction there is a change in tidal volume before suction is $506+103$ to $483+101 \mathrm{ml}$. Hoellering, (2008) investigated the effect of open and closed endotracheal suction on lung volume and cardiorespiratory changes in neonates with a suction pressure of $150 \mathrm{mmHg}$, where there was a change in the minimum oxygen saturation in the use of the closed suction method was $92.0 \%$ and in the open suction the oxygen saturation value was $86 \%$.

Regulatory negative pressure from effective suction is needed by patients treated in critical care, especially in patients with head injuries, because in intensive care the procedure is a routine treatment and head injury patients require adequate oxygen saturation to prevent the occurrence of injury secondary to hypoxia and increased intracranial pressure. Research conducted by Lesmana, Murni and Anna (2015) the use of suction pressures of $100 \mathrm{mmHg}, 120 \mathrm{mmHg}$ and $150 \mathrm{mmHg}$, must consider the amount of mucus and oxygen saturation after hyper oxygenation, if the patient's oxygen saturation is $<95 \%$ after hyper oxygenation the administration of pressure is $100 \mathrm{mmHg}$ can be considered, but if the number of mucus is large and after administration of oxygen oxygenation hyper oxygenation patients $>95 \%$ can use suction pressures of $120 \mathrm{mmHg}$ and $150 \mathrm{mmHg}$.

American Association for Respiratory Care (2010) recommends to always adjust the pressure before suctioning is done by closing the end of the hose that connects the suction catheter with a mucus container then the recommended pressure $(100 \mathrm{mmHg}-150 \mathrm{mmHg})$ is regulated by rotating the pressure regulator (vacum regulator) contained in the suction control device. Excessive use of suction pressure (> $150 \mathrm{mmHg}$ ) can cause a decrease in oxygen saturation, injury to the airway and cause alveoli collapse. Research conducted by Leur, Zwapeling, Loef 
and Schans (2003) states that the use of suction pressures of 200 - $400 \mathrm{mmHg}$ can cause airway mucosal damage, prolonging hospital days to be fatal, causing death.

\subsection{Suction Catheter Size}

The use of suction catheters must be based on the size of the endotracheal used by the patient. Suction catheters larger than half the diameter of the endotracheal tube can cause an increased incidence of hypoxemia, hypoxia, tracheal mucosal injury and atelectasis. Kelleher and Andrews (2008), in their research recommend the use of suction catheters less than the diameter of the endotracheal tube. Hahn (2010), advocates the use of suction catheters based on formulas; $\mathrm{Fr}=($ ETT size -1$) \times 2$ because this formula is quite effective. Based on research conducted by Day, Farnell, Haynes, Wainwright and Barnett (2002), recommend the use of suction catheters based on the formula; $\mathrm{Fr}=($ ETT size -2$) \times 2$. But the use of smaller suction catheters can cause ineffective evacuation of secretions so the general recommendation of using a suction catheter is less than half the internal diameter of the lumen of the endotracheal tube.

\subsection{Time/ duration of Suctioning}

The recommended time in the implementation of suction is for adult patients 10-15 seconds while for infants and children is 5 seconds, if more than this time can cause hypoxemia and trauma (Day, Farnell, Haynes, Wainwright \& Barnett, 2002).

Kelleher and Andrews (2008) recommend that the implementation time of suction in adult patients is $\leq 15$ seconds. Hahn (2010) recommends that the suction time for adult patients is 10 15 seconds while for infants and young children is $\leq 5$ seconds.

\subsection{Suction Technique}

Suction techniques in the endotracheal tube and tracheostomy are divided into two, namely open suction techniques and closed suction techniques (in line). Open systems have several advantages and disadvantages. The advantage of open suction technique is that more secretions are smoked when compared to the closed suction system while the loss is more at risk of hypoxia due to the disconnection of the source of oxygen therapy with the patient when suction is performed, the risk of contamination of patient secretions to nurses is greater so nurses are required to use protective equipment yourself while doing suction. The advantage of closed suction system techniques is to prevent loss of lung volume during suction so that the incidence of hypoxia is lower, reducing the spread of infection between patients and caregivers. While the disadvantages of closed suction system techniques are the number of secretions that are smoked less (when compared to the open system) and the suction catheters used are more expensive and sometimes not covered by the insurance system (Berman, Snyder, Kozier \& Erb, 2009; Hahn, 2010). 


\subsection{Volume and Viscosity Mucus}

Mucus secreted by epithelial goblet cells from the submucosal glands. The amount of mucus is also controlled by the parasympathetic nervous system and neurohormonal situations so that each individual varies in mucus / mucus production in one day. Under normal circumstances, the adult respiratory system produces mucus / mucus approximately $100 \mathrm{cc}$ every day. The production of airway mucus can increase due to stimulation of the mucous membrane physically, chemically or infection, including the action of endotracheal intubation and cannula tracheostomy. Because of these stimuli mucus production can increase up to 1 liter every day. Mucus consistency can be classified as runny, thick to sticky. In the mucus that comes from the lower respiratory tract alveolar macrophages will be found and in the upper mucus of the larynx will be found in many squamous cells. The effectiveness of the use of negative pressure from suction is also influenced by the size of the suction catheter, the number and viscosity of the mucus and the duration of the suction time (Djojodibroto, 2009; Hahn, 2010).

Based on research conducted by Lopez, Pearce, Narron Perez and Rubin (2010), the use of minimal suction pressure has been proven to be able to evacuate secretions from the airways in patients with endotracheal tube attachments $(\mathrm{p}=0.0006)$ and at high suction pressures can also evacuating respiratory secretions in patients with endotracheal tube intervals $(p=0.001)$. Suction pressure between $100 \mathrm{mmHg}-150 \mathrm{mmHg}$ can evacuate secretions in patients with endotracheal tubes, but in patients who have respiratory infections where the viscosity of the secretions increases (yellow secretions / greenish), a maximum pressure is needed to evacuate the secretions. This is in accordance with research conducted by Lasocki, et.al. (2006), where the greater use of negative suction pressure would increase the mucus removal ability from the airway but there was also an increase in lung volume loss especially in the open suction technique $(\mathrm{p}=0.02)$.

Changes in vital signs before suction is an indication of the presence of mucus in the respiratory tract, where when mucus partially closes the airways there will be a decrease in tidal volume which results in a decrease in oxygen saturation, so the body compensates with an increase in respiratory rate and increased heart rate (Schell \& Puntilo, 2006; Potter \& Perry, 2010).

The effect of this suctioning also affects the changes in vital signs of the patient. Changes occur mainly in heart rate, breathing frequency, blood pressure, mean arterial pressure, cardiac output and pulmonary arterial pressure after suctioning. Research conducted by Lucchini, et. al. (2012), after suctioning an increase in heart rate was $2.93 \%(p=0.02)$.

Changes in vital signs are caused by when the suction catheter touches the karina (cough receptor), thus stimulating the patient to cough. When the coughing process occurs, there is inspiration in quickly, there by increasing intra thoracic pressure, abdominal muscles contracting and intercostal internal muscular contractions, causing the diaphragm to rise and 
lung pressure to increase (up to $100 \mathrm{mmHg}$ ) and then air expiration (expiration) fast and hard (created air speeds of $16,000-24,000 \mathrm{~cm} / \mathrm{min}$ ). Increased respiratory frequency due to irregularity in respiratory patterns (rapid inspiration and expiration) due to cough response (due to cough receptor stimulus by suction catheters that touch the carina). Increased systolic blood pressure due to increased afterload resulting from increased intra-abdominal pressure which stimulates to increase stroke volume to ensure adequate cardiac output. An increase in diastolic blood pressure results from an increase in intra thoracic pressure which causes a bottleneck in the atrial filling phase (increased intraatrial pressure), resulting in an increase in preload pressure. Increased systolic and diastolic blood pressure results in increased mean arterial pressure (MAP) (Guyton, AC \& Hall, JE, 2010; Almgren, B., Wickerts, CJ., Heinonen, E., \& Hogman, M., 2003).

\section{Conclusion}

Factors that influence the effectiveness of suction measures consist of 7 factors, are; assessment before performing suction, pre-hyper oxygenation measures, effective suction pressure regulation, suction canule size must pay attention to the ETT diameter / size, suction action time 10-15 seconds for adults and 5 seconds for infants and children, suction techniques and must consider volume and mucus viscosity. The conclusion in conducting effective suction, nurses must pay attention to these 7 factors rather in the implementation of suction actions to be more effective and avoid unwanted side effects.

\section{REFERENCES}

[1] Almgren, B., Wickerts, CJ., Heinonen, E., Hogman, M., (2004). Side Effects of Endotracheal Suction in Pressure and Volume Controlled Ventilation. Chestjournal.org. September 26, 2019. From http://www.google.co.id.chestjournal.chest.

[2] American Association for Respiratory Care. (2010). Endotracheal Suctioning of Mechanically Ventilated Patients With Artificial Airways 2010. AARC Clinical $\begin{array}{llll}\text { Practice } \quad \text { Guidelines. } & \text { September 2019. From }\end{array}$ http://www.apicwv.org/docs/1.pdf.

[3] Berman, A. Snyder, S. Kozier, B. \& Erb, G. (2009). Buku Ajar Praktik Keperawatan Klinis. Edisi 5. Terjemahan Eny meiliya, Esty Wahyuningsih, Devi Yulianti dan Fruriolina Ariani. Jakarta: PT. EGC.

[4] Cereda, et.al. (2001). Closed System Endotracheal Suctioning Maintains Lung Volume During Volume Controlled Mechanical Ventilation. Intensive Care Medicine. Volume 27. September 26, 2019. From www.ncbi.nlm.nih.gov/pubmed/11398690.

[5] Corley, et.al. (2010). Open and Closed Suctioning Result in Significant Lung derecruitment. Anaesthesia and Intensive Care Volume 38. September 26, 2019. From http://espace.library.uq.edu.au/view/UQ:28154. (1/02/13).

[6] Day, T. Farnell, S. Haynes, S. Wainwright, S. \& Bernett, J.W. (2002). Tracheal Suctioning : an Exploration of Nurses' Knowledge and Competence In Acute and 
High Depedency Ward Areas. September 26, 2019. From http://web.ebscohost.com/ehost/19.

[7] Djojodibroto, D. (2009). Respirologi (Respiratory Medicine). Jakarta: PT. EGC.

[8] Guyton, A.C. \& Hall, J.E. (2010). Buku Ajar Fisiologi Kedokteran. Edisi 9. Jakarta: PT. EGC.

[9] Hahn, M. (2010). 10 Consideration for Endotracheal Suctioning. rtmagazine.com. September 26, 2019. From http://web.ebscohost.com/ehost/pdfviewer/19

[10] Heinze, H., et.al. (2008). Functional residual capacity changes after different endotracheal suctioning methods. Anesth Analg. Volume. 107. September 26, 2019. From http://www.ncbi.nlm.nih.gov/pubmed/18713910.

[11] Hoellering, A.B. Copnell, B. Dargaville, P.A., Mills, J.F. Morley, C.J. \& Tingay, D.G. (2008). Lung Volume and Cardiorespiratory Changes During Open and Closed Endotracheal Suction in Ventilated Newborn Infants. September 26, 2019. From http://web.ebscohost.com/ehost/pdfviewer/118.

[12] Kelleher, S. \& Andrews, T. (2006). An Observational Study On The Open-System Endotracheal Suctioning Practices Of Critical Care Nurses. September 26, 2019. From http://web.ebscohost.com/ehost/pdfviewer/19.

[13] Kozier, B. Erb, G. Berman, A \& Snyder, S.J. (2011). Buku Ajar Fundamental Keperawatan, Konsep, Proses dan Praktik. Jakarta: PT. EGC.

[14] Lasocki, S. et.al. (2006). Open and Closed-circuit Endotracheal Suctioning in Acut Lung Injury. Anesthesiology Volume 104. September 26, 2019. From http://www.google.co.id/url2FDocumentation.

[15] Lesmana, H., Murni, T. W., \& Anna, A. (2015). Analisis Dampak Penggunaan Varian Tekanan Suction terhadap Pasien Cedera Kepala Berat. Jurnal Keperawatan Padjadjaran, 3(3). September 26, 2019. From http://jkp.fkep.unpad.ac.id/index.php/jkp/article/view/114.

[16] Leur, JP., Zwavelng, JH., Loef, BG., Schans, CP. (2003). Endotracheal Suctioning Versus Minimally Invasive Airway Suctioning in Intubated Patients : A Prospective Randomised Controlled Trial. September 26, 2019. From www.ncbi.nlm.nih.gov/pubmed/12577156

[17] Lopez, KL., Pearce, MA., Narron, KA., Perez, J. \& Rubin, BK. (2010). In Vitro Evaluation of Endotracheal Tubes With Intrinsic Suction. Chest Journal 138 (4). September 26, 2019. From http://www.ncbi.nlm.nih.gov/pubmed/20363842.

[18] Lucchini, A., et.al. (2011). Tracheal Secretion Management In The Mechanically Ventilated Patient : Comparison Of Standard Assessment And An Acoustic Secretion Detector. September 26, 2019. From http://web.ebscohost.com/ehost/pdfviewer/19.

[19] Oh, H. \& Seo, W. (2003). A Meta-analysis of The Effects of Various Interventions in Preventing Endotracheal Suction Induced Hypoxemia. Journal of Clinical Nursing Volume 12. September 26, 2019. From http://web.ebscohost.com/ehost/pdfviewer/28.

[20] Potter, P.A. \& Perry, A.G. (2010). Buku Ajar Fundamental Keperawatan. Buku 3. Edisi 7. Jakarta: Salemba Medika.

[21] Schell, H.M. \& Puntilo, K.A. (2006). Nursing Secrets Series Critical Care Nursing Secrets. Second Edition. Philadelphia: Mosby Elsevier.

[22] Seymour, C.W., Cross, B.J. Cooke, C.R., Gallop, R.L., \& Fuchs, B.D. (2009). Physiologic Impact of Closed-System Endotracheal Suctioning in Spontaneously Breathing Patients Receiving Mechanical Ventilation. Journal Respiratory $\begin{array}{lllll}\text { Care } & \text { Vol 2019. } & \text { From }\end{array}$ http://web.ebscohost.com/ehost/pdfviewer/107.

[23] Woodward, S \& Mestecky, A.M. (2011). Neuroscience Nursing EvidanceBasedPractice. United Kingdom: Wiley-Blackwell. 